\title{
Newborns with staphylococcus aureus and coagulase-negative sepsis treated with vancomycin after an increase in serum levels around the valley
}

\section{Open acess}

${ }^{1}$ Estudante de graduação. Programa de Iniciação Científica. Faculdade de Medicina da Universidade de São Paulo.

${ }^{2}$ Professor Titular Terapia IntensivaNeonatologia do Instituto da Criança- Hospital das Clínicas da Faculdade de Medicina da Universidade de São Paulo. Graduado em Medicina, Faculdade de Ciências Médicas de Santos (1977), Título de Especialista em Terapia Intensiva e Neonatologia, em Nutrição Parenteral e Enteral. Atualmente é Chefe da UTI Hospital Santa Catarina.

${ }^{3}$ Livre Docente. Chefe da UT neonatal do Instituto da Criança. Coordenadora de Ensino da Disciplina de Neonatologia e de Pesquisa da UTI Neonatal

\section{Corresponding author:} maria.esther@hc.fm.usp.br

Manuscript received: October 2017 Manuscript accepted: December 2017 Version of record online: March 2018

\section{Rosane Okasaki ${ }^{1}$, Werther Brunow de Carvalho², Maria Esther Jurfest Rivero Ceccon ${ }^{3}$}

Abstract

Introduction: Vancomycin is a glycopeptide antibiotic considered the gold standard in the treatment of staphylococcal infections that are oxacillin-resistant.

Objective: To analyse the concentration of serum level in the voucher (one hour before the next administration of the drug dose) of vancomycin in newborns with Staphylococcus aureus infection or oxacillin-resistant coagulase-negative.

Methods: This is an experimental study with data collection between the years 2001 and 2016 . We selected 30 patients who had staphylococcus aureus and coagulase-negative sepsis and used vancomycin as a treatment. We collected and recorded their serum levels.

Results: Of the 30 patients included in the present study, $80 \%$ were preterm. Among all the newborns, mean serum concentrations in the vancomycin valley were $40 \%$ adequate, $13.34 \%$ lower than expected, and $46.67 \%$ higher than the reference values. In seven patients $(23.34 \%)$, the first serum level in the Vancomycin valley collected was adequate, but in nine (30\%) and $14(46.67 \%)$ patients, the serum concentration in the valley was respectively below and above the correct values. After dose shifting of those who did not achieve adequate levels, only three of the 14 patients in whom the first dose was not adequate had a mean serum total level within the expected range; the remaining 11 stayed at high levels, which raised great concern due to the fact that if the infection is not being treated, the elevated serum level leads to nephrotoxic and ototoxic problems. The monitoring of serum levels in the vancomycin valley is of great importance as it minimises nephrotoxic effects, thus increasing the efficacy of the drug. The dosage adjustment of vancomycin in severely ill patients admitted to an intensive care unit is important and requires more studies related to this area, as the work of a multidisciplinary body makes the treatment better and more specific.

Conclusion: The concentrations of serum levels in the Vancomycin valley $(10-15 \mu \mathrm{g} / \mathrm{mL})$ in patients hospitalised in a neonatal intensive care unit of a reference hospital in Latin America were thought to be bactericidal; however, this is not the values observed in our study.

Keywords: vancomycin, intensive care units, neonatal, newborn, staphylococcus aureus.

Suggested citation: Okasaki R, Carvalho WB, Ceccon MEJR. Newborns with staphylococcus aureus and coagulase-negative sepsis treated with vancomycin after an increase in serum levels around the valley. J Hum Growth Dev. 2018; 28(1):9-17. DOI: http://dx.doi.org/10.7322/jhgd.143846 


\section{INTRODUCTION}

Staphylococcus aureus and coagulase-negative staphylococci are the most common infections in both neonatal and paediatric intensive care units ${ }^{1,2}$ and have a significant impact on patients' mortality and morbidity ${ }^{3-5}$. Penicillin-resistant staphylococci have emerged since the 1980s, and currently both types are sensitive to vancomycin only. For this reason, this drug has long been considered the gold standard in therapy against these infectious agents ${ }^{6}$.

The Food and Drug Administration (FDA) approved vancomycin for use in the United States in 1958 to treat penicillin-resistant1 Staphylococcus aureus infection. It is a complex, glycopeptide antibiotic containing amino acids and sugars and has high molecular ${ }^{2,3}$ weight with activity in the $\mathrm{pH}$ range between 6.0 and 8.0.

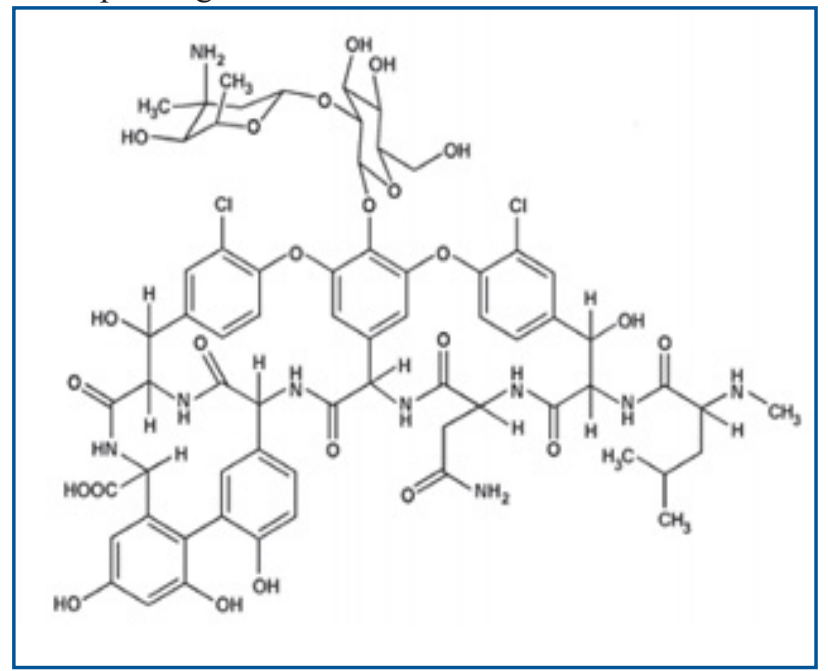

Figure : Vancomycin structure.

Source: VILA et al., 2007.

Several situations require the monitoring of serum levels and adjustment of vancomycin doses. Clinical factors such as site and severity of infection, suspected or confirmed infectious agent, underlying disease and concomitant therapies ${ }^{7}$, and the fact that the drug has a narrow therapeutic range all increase the risk of side effects, such as nephritic syndrome and ototoxicity, skin reactions (e.g., erythema), and flushing histamine-like and

\section{METHODS}

This is a retrospective descriptive and interventional study, made when the levels of the drug were outside the range of normal, performed at the Center for Neonatal Intensive Care (CTNI-2) of the Children's Institute of the Hospital das Clínicas of the University of São Paulo, which has 20 beds for newborns hospitalised in serious condition with both clinical and surgical diseases that require specialised care for more than 24 hours.

Voucher is defined as the time period of one hour before the next administration of the dose of the drug. The choice of voucher was given by being routinely dosed to indicate the levels/values of the adequate dosage of the drug in the therapeutic treatment of the newborns until the end of the drug Activity. other anaphylactic reactions, when anaesthetics are given. The association with aminoglycosides and furosemide that is frequent in the sepsis patient increases toxicity. Effects on neuromuscular blockade may be enhanced when nondepolarizing muscle relaxants are administered.

Thereareimportantinterindividual pharmacokinetic variations (age, weight, renal function) that emphasise the importance of drug monitoring and dosage adjustment in clinical practice ${ }^{8}$. However, even though vancomycin has been used for more than half a century in neonatal care, dosage and efficacy still currently demonstrate its pharmacological complexity.

Preterm infants are susceptible to higher concentrations of free and bioavailable drugs due to: decreased serum protein concentration; high fetal albumin concentration, which has decreased affinity for drug binding; low plasma $\mathrm{pH}$; which reduces protein binding to acidic drugs; and serum concentration of competing molecules at the binding of drugs with proteins, such as bilirubin and free fatty acids. Thus, a standard dose becomes an exaggerated dose and causes toxic effects. On the other hand, the greater volume of drug distribution to tissues leads to a greater need to concentrate drugs per kilo of body weight in order to maintain adequate serum concentration, since protein-free drugs are also more available to be metabolised and excreted ${ }^{9}$.

The therapeutic values for use of vancomycin, according to Neofax ${ }^{\circledR}$ (dosage book used in most Neonatal Units) up to 2009 , were $5-10 \mu \mathrm{g} / \mathrm{ml}$ for valley concentrations (4 to 8 times minimum inhibitory concentration (MIC) and $20-40 \mu \mathrm{g} / \mathrm{ml}$ for peak concentrations (10 to $30 \mathrm{MIC}$ ) at doses of $10-15 \mathrm{mg} / \mathrm{kg}^{10}$. Currently, neonatal referrals recommend higher serum concentrations in the valley of $10-15 \mu \mathrm{g} / \mathrm{ml}$, but doses remain unchanged ${ }^{11,12}$.

Thus, the objective is to analyse the concentration of serum levels in the voucher (one hour before the next administration of the drug dose) of vancomycin in newborns admitted to a neonatal intensive care unit with Staphylococcus aureus or coagulase-negative oxacillinresistant strains are adequate and according to the literature.

\section{Inclusion criteria}

We obtained a list of patients who, according to the registry of the unit and the hospital, were admitted to the neonatal ICU of the Children's Institute and had a diagnosis of sepsis by Staphylococcus aureus and/or coagulasenegative. From this list, we randomised newborns (under the age of one year) that were hospitalised between 2001 and 2016 and of life was done. We obtained data collected at the time of administration of vancomycin (i.e., weight, age, gestational age, administered doses of vancomycin, and serum levels) from the medical records of patients with bloodstream infection by Staphylococcus aureus and coagulase-negative using vancomycin as a form of treatment. 


\section{Exclusion criteria}

We excluded patients whose medical records had no serum level registry in the vancomycin voucher or who did not receive it as a form of treatment. All patients who had serum levels in the vancomycin valley below, adequate, or above the reference values were included, even though the admission period of these patients had different serum levels of reference.

The prescription of vancomycin was made according to the literature followed, Neofax ${ }^{\circledR}$, which suggests doses according to the weight and gestational age of the newborn. The suggested doses are $10-15 \mathrm{mg} /$ $\mathrm{kg}$ with intervals of administration followed empirically; thus, they could be $6 / 6$ hours, $8 / 8$ hours, $12 / 12$ hours, $18 / 18$ hours, up to $24 / 24$ hours, depending on the serum

\section{RESULTS}

Thirty newborns (13 females, 43.4\%) were included, of which $24(80 \%)$ were premature. The mean age at which vancomycin treatment was started was 21.94 days. Through the records of laboratory tests performed, blood cultures were positive for Staphylococcus aureus level in the vancomycin vial (i.e., above or below the reference value of $10-15 \mu \mathrm{g} / \mathrm{ml}$ ), the time interval of drug administration was modified.

The vancomycin voucher as quoted in the introduction is one hour before the next administration of the drug and represents the efficacy thereof, which must still be between the desired values (i.e., it would still be acting even at the end of the time before the next dose.

Data collected from serum levels were statistically analysed using means, medians, standard deviations, and $\%$ mean deviation. The present study was approved by the Research and Ethics Committee of the Department of Pediatrics, Faculty of Medicine, University of São Paulo (protocol number: 1.684976).

in 12 patients and blood culture positive for S. coagulasenegative 18 newborns (Table 1 and Table 2). Of the 30 newborns, $12(40 \%)$ had adequate mean serum levels, but four (13.34\%) had mean values below that expected and 14 (46.67\%) had means above the reference values (Table 3).

Table 1: Demographic data of the 30 patients studied. Brazil, 2018

\begin{tabular}{|c|c|c|c|c|c|c|}
\hline Case & Year & Age & $\begin{array}{l}\text { Age when administered } \\
\text { vancomycin }\end{array}$ & Gestacional age & Weigth & Sex \\
\hline 1 & 2001 & 14 days & 17 days & 41 weeks & $2515 \mathrm{~g}$ & M \\
\hline 2 & 2004 & 9 days & 21 days & 29 weeks & $1120 \mathrm{~g}$ & M \\
\hline 3 & 2005 & 1 day & 20 days & 28 weeks & $1130 \mathrm{~g}$ & $M$ \\
\hline 4 & 2005 & 1 day & 9 days & 28 weeks & $1220 \mathrm{~g}$ & $\mathrm{~F}$ \\
\hline 5 & 2005 & 16 days & 20 days & 39 weeks & $3200 \mathrm{~g}$ & $M$ \\
\hline 6 & 2006 & 25 days & 28 days & 36 weeks & $2420 \mathrm{~g}$ & $\mathrm{~F}$ \\
\hline 7 & 2006 & 9 days & 20 days & 40 weeks & $3300 \mathrm{~g}$ & $\mathrm{~F}$ \\
\hline 8 & 2006 & 1 day & 8 days & 28 weeks & $690 \mathrm{~g}$ & $\mathrm{~F}$ \\
\hline 9 & 2007 & 26 days & 37 days & 40 weeks & $3780 \mathrm{~g}$ & $M$ \\
\hline 10 & 2007 & 1 day & 10 days & 31 weeks & $1590 \mathrm{~g}$ & $M$ \\
\hline 11 & 2007 & 30 days & 34 days & 31 weeks & $1450 \mathrm{~g}$ & $\mathrm{~F}$ \\
\hline 12 & 2007 & 10 days & 10 days & 33 weeks & $1085 \mathrm{~g}$ & $\mathrm{~F}$ \\
\hline 13 & 2007 & 1 day & 4 days & 28 weeks & $635 \mathrm{~g}$ & $M$ \\
\hline 14 & 2008 & 5 days & 10 days & 32 weeks & $1430 \mathrm{~g}$ & $M$ \\
\hline 15 & 2008 & 19 days & 24 days & 36 weeks & $3300 \mathrm{~g}$ & $\mathrm{~F}$ \\
\hline 16 & 2008 & 8 days & 12 days & 35 weeks & $2300 \mathrm{~g}$ & $\mathrm{~F}$ \\
\hline 17 & 2009 & 51 days & 61 days & 35 weeks & $3710 \mathrm{~g}$ & $M$ \\
\hline 18 & 2009 & 1 day & 9 days & 34 weeks & $1120 \mathrm{~g}$ & $\mathrm{~F}$ \\
\hline 19 & 2009 & 25 days & 23 days & 33 weeks & $960 \mathrm{~g}$ & $M$ \\
\hline 20 & 2009 & 8 days & 8 days & 35 weeks & $1935 \mathrm{~g}$ & $\mathrm{~F}$ \\
\hline 21 & 2009 & 65 days & 67 days & 35 weeks & $1620 \mathrm{~g}$ & $M$ \\
\hline 22 & 2012 & 2 days & 7 days & 41 weeks & $3675 \mathrm{~g}$ & $M$ \\
\hline 23 & 2013 & 22 days & 22 days & 31 weeks & $935 \mathrm{~g}$ & $\mathrm{~F}$ \\
\hline 24 & 2013 & 1 day & 36 days & 37 weeks & $2882 \mathrm{~g}$ & $M$ \\
\hline 25 & 2015 & 56 days & 57 days & 31 weeks & $1125 \mathrm{~g}$ & $M$ \\
\hline 26 & 2016 & 29 days & 32 days & 33 weeks & $1600 \mathrm{~g}$ & $\mathrm{~F}$ \\
\hline 27 & 2016 & 4 days & 8 days & 34 weeks & $1925 \mathrm{~g}$ & $\mathrm{~F}$ \\
\hline 28 & 2016 & 19 days & 24 days & 25 weeks & $810 \mathrm{~g}$ & $\mathrm{~F}$ \\
\hline 29 & 2016 & 1 day & 8 days & 32 weeks & $1050 \mathrm{~g}$ & $M$ \\
\hline 30 & 2016 & 1 day & 12 days & 35 weeks & $2300 \mathrm{~g}$ & $M$ \\
\hline
\end{tabular}

M; male, F; female 
Table 2: Laboratory tests and diagnosis of the 30 patients studied. Brazil, 2018

\begin{tabular}{|c|c|c|}
\hline Case & Laboratory exams & Diagnosis Sepse provein \\
\hline 1 & $\mathrm{HMC}+$ for S Aeureus & RNT AIG \\
\hline 2 & $\mathrm{HMC}+$ for $\mathrm{S}$ aureus & RNPT MBP AIG \\
\hline 3 & $\mathrm{HMC}+$ and catheter tip for S. coagulase negative & RNPT MBP AIG \\
\hline 4 & $\mathrm{HMC}+$ for $\mathrm{S}$ coagulase negative & RNPT MBP AIG \\
\hline 5 & $\mathrm{HMC}$ - for $\mathrm{S}$ coagulase negative & RNT AIG \\
\hline 6 & $\mathrm{HMC}$ - for $\mathrm{S}$ coagulase negative & RNPT BP .AIG \\
\hline 7 & $\mathrm{HMC}+$ for $\mathrm{S}$. Aureus & RNT AIG \\
\hline 8 & $\mathrm{HMC}+$ for $\mathrm{S}$ coagulase negative & RNPT MMBP PIG \\
\hline 9 & $\mathrm{HMC}+$ and catheter tip for $\mathrm{S}$. coagulase negative & RNT GIG \\
\hline 10 & $\mathrm{HMC}+$ and catheter tip for $\mathrm{S}$. aureus & RNPT BP AIG \\
\hline 11 & $\mathrm{HMC}+$ for $\mathrm{S}$ coagulase negative & RNPT MBP AIG \\
\hline 12 & $\mathrm{HMC}+$ for $\mathrm{S}$ coagulase negative & RNPT MBP PIG \\
\hline 13 & $\mathrm{HMC}+$ for $\mathrm{S}$ coagulase negative & RNPT MMBP PIG \\
\hline 14 & $\mathrm{HMC}$ and catheter tip for $\mathrm{S}$ coagulase negative & RNPT MBP AIG \\
\hline 15 & Culture of ocular secretion + para $\mathrm{S}$ aureus and $\mathrm{HMC}+$ for $\mathrm{S}$ aureus & RNPT GIG \\
\hline 16 & $\mathrm{HMC}+$ for $\mathrm{S}$. Aureus & RNPT BP .AIG \\
\hline 17 & $\mathrm{HMC}+$ for $\mathrm{S}$ aureus e Enterococcus faecalis & RNPT GIG \\
\hline 18 & $\mathrm{HMC}+$ for $\mathrm{S}$. Aureus & RNPT MPB PIG \\
\hline 19 & $\mathrm{HMC}+$ for $\mathrm{S}$ coagulase negative & RNPT MMBP PIG \\
\hline 20 & $\mathrm{HMC}+$ for $\mathrm{S}$. coagulase negative & RNPT BP .AIG \\
\hline 21 & $\mathrm{HMC}+$ for $\mathrm{S}$. aureus e Enterococcus faecalis & RNPT BP .AIG \\
\hline 22 & $\mathrm{HMC}+$ for $\mathrm{S}$. coagulase negative & RNT AIG \\
\hline 23 & $\mathrm{HMC}+$ for $\mathrm{S}$ coagulase negative & RNPT MMBP PIG \\
\hline 24 & $\mathrm{HMC}+$ for $\mathrm{S}$. coagulase negative & RNT AIG \\
\hline 25 & $\mathrm{HMC}+$ for $\mathrm{S}$. coagulase negative & RNPT MBP AIG \\
\hline 26 & $\mathrm{HMC}+$ for $\mathrm{S}$. Aureus & RNPT BP .AIG \\
\hline 27 & $\mathrm{HMC}+$ for $\mathrm{S}$. Aureus & RNPT BP .AIG \\
\hline 28 & $\mathrm{HMC}+$ for $\mathrm{S}$ coagulase negative & RNPT MMBP AIG \\
\hline 29 & $\mathrm{HMC}+$ and catheter tip for $\mathrm{S}$. Aureus & RNPT MBP PIG \\
\hline 30 & $\mathrm{HMC}+$ for $\mathrm{S}$ coagulase negative & RNPT BP AIG \\
\hline
\end{tabular}

HMC - - hemocukura positive; RNT - term new born; R.XPT -pre-term new born; AÍG - adequate for gestational age:

PIG - small for gestational age; GIG - big for gestational age; BP - Low weight; MBP - very low weight; MMPB - very very low weight

Table 3: Serum levels in the vancomycin voucher of the 30 patients studied

\begin{tabular}{|c|c|c|c|c|c|c|c|}
\hline Case & Year & $\begin{array}{c}\text { SL vancomycin } \\
\text { voucher }\end{array}$ & $\begin{array}{l}\text { Average of SL } \\
\text { voucher }\end{array}$ & Median & $\begin{array}{l}\text { Minimal values } \\
\text { of SL in voucher }\end{array}$ & $\begin{array}{l}\text { Maximum values } \\
\text { of SL in voucher }\end{array}$ & $\begin{array}{l}\text { Standard } \\
\text { deviation }\end{array}$ \\
\hline 1 & 2001 & 9,6 & 9,6 & 9,6 & 9,6 & 9,6 & \\
\hline 2 & 2004 & $\begin{array}{l}4,1 \\
7,1\end{array}$ & 5,6 & 5,6 & 4,1 & 7,1 & \\
\hline 3 & 2005 & $\begin{array}{l}25,1 \\
11\end{array}$ & 18,1 & 18,1 & 11 & 25,1 & \\
\hline 4 & 2005 & $\begin{array}{l}22,7 \\
2,4 \\
10 \\
10\end{array}$ & 11,3 & 10 & 2,4 & 22,7 & \\
\hline 5 & 2005 & $\begin{array}{l}27,57 \\
5,7\end{array}$ & 16,64 & 16,64 & 5,7 & 27,7 & \\
\hline 6 & 2006 & $\begin{array}{l}9,6 \\
10,3 \\
31,2 \\
2,5\end{array}$ & 13,4 & 10 & 2,5 & 31,2 & \\
\hline 7 & 2006 & 10,9 & 10,9 & 10,9 & 10,9 & 10,9 & \\
\hline 8 & 2006 & $\begin{array}{l}4,76 \\
9,05 \\
4,5\end{array}$ & 6,1 & 4,76 & 4,5 & 9,05 & \\
\hline
\end{tabular}


continuation: Table 3: Serum levels in the vancomycin voucher of the 30 patients studied

\begin{tabular}{|c|c|c|c|c|c|c|c|}
\hline Case & Year & $\begin{array}{l}\text { SL vancomycin } \\
\text { voucher }\end{array}$ & $\begin{array}{c}\text { Average of SL } \\
\text { voucher }\end{array}$ & Median & $\begin{array}{l}\text { Minimal values } \\
\text { of } S L \text { in voucher }\end{array}$ & $\begin{array}{l}\text { Maximum values } \\
\text { of SL in voucher }\end{array}$ & $\begin{array}{l}\text { Standard } \\
\text { deviation }\end{array}$ \\
\hline 9 & 2007 & 4,92 & 4,92 & 4,92 & 4,92 & 4,92 & \\
\hline 10 & 2007 & $\begin{array}{l}7,09 \\
11 \\
14,4 \\
8 \\
13,07 \\
7,46\end{array}$ & 10,17 & 7,46 & 7,9 & 14,4 & \\
\hline 11 & 2007 & 5,5 & 5,5 & 5,5 & 5,5 & 5,5 & \\
\hline 12 & 2007 & $\begin{array}{l}20,3 \\
5,9 \\
4,3\end{array}$ & 10,2 & 5,9 & 4,3 & 20,3 & \\
\hline 13 & 2007 & $\begin{array}{l}105 \\
19,4 \\
7\end{array}$ & 12,3 & 10,5 & 7 & 19,4 & \\
\hline 14 & 2008 & $\begin{array}{l}13,7 \\
4 \\
9,7\end{array}$ & 9,1 & 9,7 & 4 & 13,7 & \\
\hline 15 & 2008 & 7,5 & 7,5 & 7,5 & 7,5 & 7,5 & \\
\hline 16 & 2008 & $\begin{array}{l}12,9 \\
2,2\end{array}$ & 7,6 & 7,6 & 2,2 & 12,9 & \\
\hline 17 & 2009 & 10 & 10 & 10 & 10 & 10 & \\
\hline 18 & 2009 & 13,3 & 13,3 & 13,3 & 13,3 & 13,3 & \\
\hline 19 & 2009 & $\begin{array}{l}77,8 \\
19,5 \\
8,2 \\
17 \\
6,9\end{array}$ & 25,9 & 17 & 6,9 & 77,8 & \\
\hline 20 & 2009 & $\begin{array}{l}11,3 \\
11,5 \\
12,5\end{array}$ & 11,8 & 11,5 & 11,3 & 12,5 & \\
\hline 21 & 2009 & $\begin{array}{l}9,5 \\
6,4 \\
7,8 \\
9,5 \\
6,9\end{array}$ & 8 & 7,8 & 6,4 & 9,5 & \\
\hline 22 & 2012 & $\begin{array}{l}4,1 \\
9\end{array}$ & 6,6 & 6,6 & 4,1 & 9 & \\
\hline 23 & 2013 & $\begin{array}{l}9,4 \\
9,9 \\
16,1 \\
23,9 \\
12,9\end{array}$ & 14,4 & 12,9 & 9,4 & 23,9 & \\
\hline 24 & 2013 & $\begin{array}{l}6,6 \\
14,3\end{array}$ & 10,5 & 10,5 & 6,6 & 14,3 & \\
\hline 25 & 2015 & $\begin{array}{l}9,5 \\
28,6 \\
8,6 \\
18,2 \\
14,2 \\
73,1 \\
5,4 \\
7,8\end{array}$ & 20,7 & 11,9 & 5,4 & 73,1 & \\
\hline 26 & 2016 & $\begin{array}{l}17,1 \\
11,2\end{array}$ & 14,2 & 14,2 & 11,2 & 17,1 & \\
\hline 27 & 2016 & 8,1 & 8,1 & 8,1 & 8,1 & 8,1 & \\
\hline 28 & 2016 & 25,5 & 25,5 & 25,5 & 25,5 & 25,5 & \\
\hline 29 & 2016 & 20,7 & 20,7 & 20,7 & 20,7 & 20,7 & \\
\hline 30 & 2016 & 3,6 & 3,6 & 3,6 & 3,6 & 3,6 & \\
\hline
\end{tabular}


After 72 hours, the 30 newborns had serum levels in the vancomycin vouchers reassessed. Among them, seven $(23.34 \%)$ had an adequate serum level, and nine $(30 \%)$ and $14(46.67 \%)$ had serum levels below and above the literature reference values, respectively. Thus, there was a change in dose and/or dosing interval prescribed for newborns that had lower- and higher-than-expected serum levels, collecting a second serum level after three days. It can be verified that of those who had the first serum level in the appropriate vancomycin valley $(23.34 \%)$ and below $(30 \%)$ of the reference, $13.24 \%$ of the patients in both cases had a total mean serum level adequately collected with a correct dosage adjustment. However, the 14 patients who had a high score at the first serum level collection in the valley and had their doses of vancomycin modified. It was observed that the mean of all serum levels of 11 of these patients $(36.67 \%)$ remained high and only three $(10 \%)$ were adequate.

Only 11 patients $(36.67 \%)$ had the first serum level in the registered vancomycin voucher. Among them, three $(10 \%)$ were below the reference values and four (13.34\%) were at adequate levels as the same amount of patients with the high levels (Graph 1).

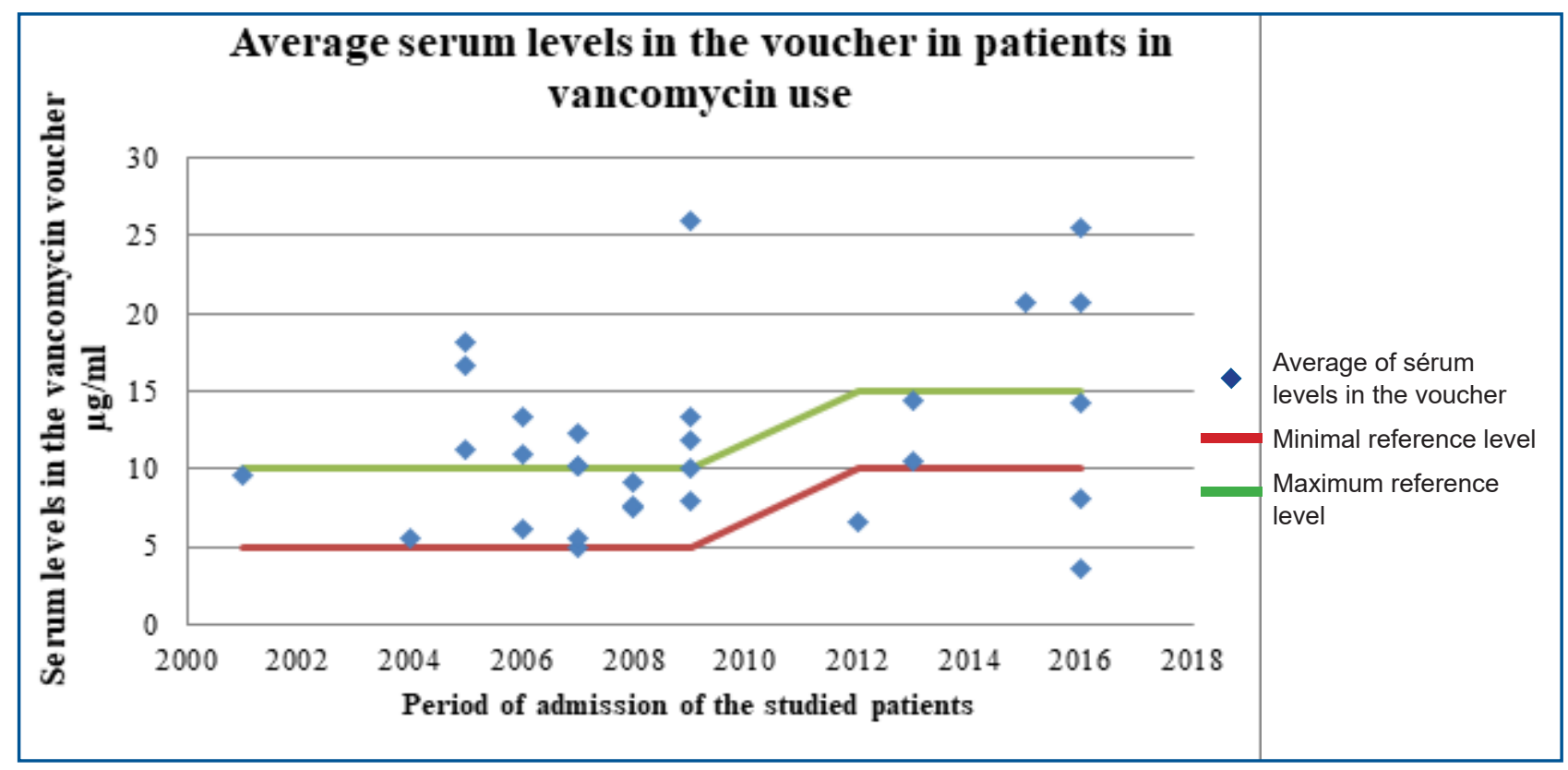

Graph 1: Average serum levels in the Vancomycin valley of studied patients. 12 RN (40\%) appropriate levels $4(13.34 \%)$ level below expected and 14 (46.67) The average serum levels gave above the reference values

\section{DISCUSSION}

The analysis of the serum levels in the vancomycin valley showed that $60 \%$ of the patients were outside the proposed targets, of which $13.64 \%$ were below the expected level and $46.36 \%$ were above reference values. Serum levels below therapeutic levels are of great concern because there is a delay in the treatment of the infection as well as a greater susceptibility to resistance of the bacteria, forcing the clinician to increase the dosage empirically. Elevated serum levels are also of concern, as they can lead to nephrotoxic and ototoxic problems.

It is noteworthy that the meeting of these increased and low levels, since they are empirically adjusted and for a preterm NB a high dose of Vancomycin can cause renal failure. The waiting procedure for the dose in the valley is adequate and promotes evolution of the infection picture of the newborn.

Another issue of difficult therapeutic management is reaching therapeutic levels in neonates with renal dysfunction, due to the fact that glomerular filtration is responsible for the excretion of vancomycin and also for tubular functions in neonates still immature ${ }^{13,14}$. Of the 30 newborns, $25 \%$ had elevated serum levels and presented renal problems treated with furosemide to improve renal function. In a situation such as this, the half-life of vancomycin may increase from 150-250 hours and provide an increase in the serum concentration of the drug and risk of toxicity, culminating in clinical worsening of the newborn ${ }^{15}$. Dialysis is the gold standard for the reversal of the clinical condition of the newborn and clearance and elimination of vancomycin.

However, in 2007 alone, there were guidelines published through the Infectious Diseases Society of America, along with other professional organisations, with multidisciplinary guidance on this program ${ }^{16}$. However, as far as the neonatal area is concerned, data are lacking on the consequences of these programs ${ }^{17}$.

In the neonatal intensive care unit (ICU), there is routine and frequent use of vancomycin. Sánches et al. ${ }^{18}$ point out that vancomycin is used empirically in ICUs, making its use inappropriate. In the 1980 s, antimicrobial management programs were introduced with the aim of reducing unnecessary therapies.

It is worth mentioning that the use of vancomycin is very frequent also due to the scarcity of new antibiotics 
in the market. The discovery of new antibiotics faces a number of challenges that make research and development very difficult when compared to other types of medicine ${ }^{19}$. Pharmaceutical industries choose not to invest in the development of new antibiotics because their effectiveness only lasts for around two years due to indiscriminate use by the general population and by health professionals. Since vancomycin has been in use for more than 50 years, it must be used correctly and carefully.

Although there are modifications in the structure of vancomycin, from the introduction of quaternary ammonium salt at the C-terminal generating a second mechanism of action, resulting in better permeability of the drug in the cell wall, as well as being complementary in the inhibition of glycopeptide synthesis of the wall bacterial cell growth, with improvement in its therapeutic effects and reduction of the bacterial resistance event ${ }^{20}$, the valley dosage seems to be more adequate for the clinical conduction of the newborns, especially to avoid the toxicity produced by the drug.

In addition, vancomycin is a glycopeptide antibiotic used to treat infections caused by grampositive micro-organisms. In monitoring the dosages of vancomycin, it is possible to obtain adequate and efficient serum concentrations for the treatment of infections. It is noteworthy that there is controversy in the therapeutic management of newborns with gram-positive micro-organisms, especially in the determination and interpretation of their serum concentrations. Measurement of serum vancomycin levels (vancocinemia) may aid in the prevention of toxicity and in the adequate maintenance of therapeutic serum concentration, avoiding low tissue penetration and failure to eliminate the outbreak of infection.

\section{CONCLUSION}

The monitoring of serum levels in the vancomycin valley is of great importance and should be performed in all hospitals because sepsis has become a major public health problem as the leading cause of death of newborns
Monitoring is based on the fact that the therapeutic response depends on the concentration of the drug in the patient's bloodstream and not on the dose administered. The use of regular doses at periodic intervals does not mean constant levels in all patients due to differences in absorption, metabolism, excretion, and bioavailability of the drug administered that influence the definitive therapeutic effect. Thus, the monitoring of serum concentrations both in the peak and in the vancomycin voucher is essential to assess the toxicity or suitability of the medicine used in the clinic of the critically ill neonate.

In the majority of neonates hospitalised in the Unit of Neonatal Intensive Care of the Reference Hospital of Latin America, there was a rate of serum level in the valley raised to the expected standards, causing greater toxic injury. It is clear that the metabolism of each drug depends on the stage of disease in the patient; however, with vancomycin, it is very difficult because the concentration of the drug in the body exceeds the therapeutic range, reaching the toxic dose and often worsening the condition of the newborn. Furthermore, vancomycin is widely used in neonatal intensive care patients who are afflicted with Staphylococcus aureus and coagulase-negative.

The mean values observed in graph 1 show that of the 30 patients analysed, $12(40 \%)$ had adequate serum levels in the valley between the red and green lines $(10-15 \mu \mathrm{g} / \mathrm{mL})$. In four newborns $(13.4 \%)$, the mean level was below the expected level (below the red line, $<10 \mu \mathrm{g} / \mathrm{mL}$ ), and 14 newborns had aboveadequate serum levels (above the green line, $>15 \mu \mathrm{g} /$ $\mathrm{mL})$.

worldwide. We need more studies related to this area as well as the work of a multidisciplinary body that would both improve and specialise treatment.

\section{REFERENCES}

1. Janssen EJH, Välitalo PA, Allegaert K, Simons SH, Sherwin CM, Mounton JW, et al. Towards rational dosing algorithms for vancomycin in neonates and infants based on population pharmacokinetic modeling. Ant Agen And Che. 2015;60(2):1013-21. DOI: http://dx.doi.org/10.1128/aac.01968-15

2. Wilhelm MP, Estes L. Vancomycin. Mayo Clinic Proced. 1990 Sep; 74 (9):928-935.

3. Goodman A, Gilman A. As bases farmacológicas da terapêutica. 10th ed. Rio de Janeiro: Guanabara Koogan; 2003.

4. Jean-Baptiste N, Benjamin DK Jr, Cohen-Wolkowiez M, Fowler VG Jr, Laughon M, Clark RH, et al. Coagulase-negative staphylococcal infections in the neonatal intensive care unit. Infect Control Hosp Epidemiol. 2011;32(7):679-86. DOI: http://dx.doi.org/10.1086/660361

5. Cunha MLRS, Lopes CAM, Rugolo LMSS, Chalita LVAS. Significância clínica de estafilococos coagulase-negativa isolados de recém-nascidos. J Ped. 2002;78(4):279-88. DOI: http://dx.doi.org/10.1590/s0021-75572002000400006

6. Rybak MJ, Lomaestro BM, Rotschafer JC, Moellering RC, Craig WA, Billeter M, et al. Vancomycin therapeutic guidelines: a summary of consensus recommendations from the infectious diseases society of america, the american society of health system pharmacists, and the society of infectious diseases pharmacists. Clin Infect Dis. 2009; 49(3):325-7. DOl: http://dx.doi.org/10.1086/600877 
7. Reis AGAC, Grisi SJFE. Monitorização das concentrações séricas da vancomicina em crianças com infecções por bactérias multirresistentes. J Ped. 1996;72(4):225-9. DOI: http://dx.doi.org/10.2223/jped.617

8. Yasuhara M, Iga T, Zenda H, Okumura K, Oguma T, Yano Y, et al. Population pharmacokinetics of vancomycin in japanese adult patients. Ther Drug Monit. 1998;20 (2):139-48.

DOI: http://dx.doi.org/10.1097/00007691-199804000-00003

9. Fernandez E, Perez R, Hernandez A, Tejada P, Arteta M, Ramos JT. Factors and mechanisms for pharmacokinetic differences between pediatric population and adults. Pharmaceutics. 2011;3(1):53-72. DOI: http://dx.doi.org/10.3390/pharmaceutics3010053

10. Machado JKK, Feferbaum R, Diniz EMA, Okay TS, Ceccon MEJ, Vaz FAC. Monitoração terapêutica com vancomicina em recém-nascidos de termo com sepse: utilização e importância clínica. Rev Hosp Clínicas. 2001;56(1):17-24. DOI: http://dx.doi.org/10.1590/S0041-87812001000100004

11. Ringenberg T, Robinson C, Meyers R, Degnan L, Shah P, Siu A, et al. Achievement of therapeutic vancomycin trough serum concentrations with empiric dosing in neonatal intensive care unit patients. Pediatr Infect Dis J. 2015;34(7):742-7. DOI: http://dx.doi.org/10.1097/inf.0000000000000664

12. Elyasi $\mathrm{S}$, Khalili $\mathrm{H}$. Vancomycin dosing nomograms targeting high serum trough levels in different populations: pros and cons. Eur J Clin Pharmacol. 2016;72(7):777-88. DOI: http://dx.doi.org/10.1007/s00228-016-2063-8

13. Allegaert K, Verbesselt R, Naulaers G, Van den Anker JN, Rayyan M, Debeer A, et al. Developmental pharmacology: neonates are not just small adults. Acta Clin Belg. 2008;63(1):16-24. DOI: http://dx.doi.org/10.1179/acb.2008.003

14. Alves MLP, Melo GAN, Yamada SS, Nishiyama P. Therapeutic monitoring of vancomycin. Acta Sci Health Sci. 2012;34(2):199-204. DOI: http://dx.doi.org/10.4025/actascihealthsci.v34i2.10617

15. Almeida R, Barros EJG, Thomé FS. Vancomicina: Avaliação do uso em pacientes internados na Unidade de Terapia Intensiva. Disertação (Mestrado) - Universidade Federal do Rio Grande do Sul. Porto Alegre: 2011.

16. Dellit TH, Owens RC, McGowan Jr JE, Gerding DN, Weinstein RA, Burke JP, et al. Infectious Diseases Society of America and the Society for Healthcare Epidemiology of America guidelines for developing an institutional program to enhance antimicrobial stewardship. Clin Infect Dis. 2007;44(2):159-77. DOI: http://dx.doi.org/10.1086/510393

17. Tzialla C, Borghesi A, Serra G, Stronati M, Corsello G. Antimicrobial therapy in neonatal intensive care unit. Ital J Pediatr. 2015; 2015;41:27. DOI: http://dx.doi.org/10.1186/s13052-015-0117-7

18. Sánchez PJ, Moallem M, Cantey JB, Milton A, Michelow IC. Empiric therapy with vancomycin in the neonatal intensive care unit: let's "get smart" globally!. Ped J. 2016; 92(5):432-5. DOI: http://dx.doi.org/10.1016/j.jped.2016.06.001

19. Lewis K. Platforms for antibiotic discovery. Nat Rev Drug Discov. 2013;12(5):371-87. DOI: http://dx.doi.org/10.1038/nrd3975

20. Okano A, Isley NA, Boger DL. Peripheral modifications of $[\Psi[\mathrm{CH} 2 \mathrm{NH}] \mathrm{Tpg}$ 4]vancomycin with added synergistic mechanisms of action provide durable and potent antibiotics. Proc Natl Acad Sci U S A. 2017;114(26):E5052-61. DOI: http://dx.doi.org/10.1073/pnas.1704125114 


\section{Resumo}

Introdução: A vancomicina é um antibiótico glicopeptídico considerado padrão-ouro no tratamento de infecções por estafilococos resistentes à oxacilina.

Objetivo: Analisar a concentração do nível sérico no vale (uma hora antes da próxima administração da dose do medicamento) de vancomicina em recém-nascidos com infecção por Staphylococcus aureus ou coagulase- negativa resistente à Oxacilina.

Método: Trata-se de estudo experimental e com coleta de dados entre os anos de 2001 e 2016 . Foram selecionados randomicamente 30 pacientes que tinham como diagnóstico sepse por Staphylococcus aureus e coagulase-negativa e fizeram uso da vancomicina como forma de tratamento e tiveram seus níveis séricos coletados e registrados nos prontuários.

Resultados: Dos 30 pacientes incluídos no presente estudo, $80 \%$ eram pré-termos. Dentre todos os recém-nascidos as médias das concentrações séricas no vale da vancomicina foram de $40 \%$ adequadas, $13,34 \%$ abaixo do esperado e $46,67 \%$ acima dos valores de referência. Em 7 ppacientes $(23,34 \%)$ o primeiro nível sérico no vale da vancomicina coletado foram adequados, porém em $9(30 \%)$ e $14(46,67 \%)$ a concentração sérica no vale foi, respectivamente, abaixo e acima dos valores corretos. Após a mudança de dose daqueles que não obtiveram níveis adequados, apenas 3 dos 14 pacientes em que a primeira dose não fora adequada tiveram uma média de nível sérico total dentro do esperado, enquanto os 11 restantes permaneceram com níveis elevados, os quais causam grandes preocupações devido ao fato de além de não estar sendo tratada a infecção, o nível sérico elevado acarreta em problemas nefrotóxicos e ototóxicos. O monitoramento dos níveis séricos no vale da vancomicina é de grande importância, pois minimiza os efeitos nefrotóxicos, assim aumentando a eficácia do medicamento. $\mathrm{O}$ ajuste posológico da vancomicina em pacientes em estado grave internados em uma Unidade de Terapia Intensiva é importante e necessita de mais estudos referentes à essa área, assim como o trabalho de um corpo multidisciplinar torna o tratamento melhor e mais específico.

Conclusão: As concentrações dos níveis séricos no vale de vancomicina em pacientes internados em Unidade de cuidados intensivos neonatais de Hospital de Referencia da América Latina entre 10 e 15 $\mu \mathrm{g} / \mathrm{mL}$ para serem bactericidas no entanto não é o que observamos nesta pesquisa.

Palavras-chave: vancomicina, monitorização terapêutica, níveis séricos no vale, unidade de terapia intensiva neonatal, recém-nascidos, Staphylococcus aureus.

- The authors (2018), this article is distributed under the terms of the Creative Commons Attribution 4.0 International License (http://creativecommons.org/licenses/by/4.0/), which permits unrestricted use, distribution, and reproduction in any medium, provided you give appropriate credit to the original author(s) and the source, provide a link to the Creative Commons license, and indicate if changes were made. The Creative Commons Public Domain Dedication waiver (http://creativecommons.org/publicdomain/ zero/1.0/) applies to the data made available in this article, unless otherwise stated. 